\title{
ACTIVITIES AND SPACE USE FOR ENABLING LOCAL ECONOMY IN COASTAL LOW INCOME HOUSING
}

\author{
Dewi Septanti, Jouke M. Post, Emilia van Egmond, Masi Mohammadi \\ Department of Built Environment, Technical University of Eindhoven (TU/e), The \\ Netherlands \\ e-mail : dewi_s@arch.its.ac.id; d.septanti@tue.nl
}

\begin{abstract}
Many low income households are supported by Home Based Enterprises (HBE) for their income generation. However the settlements in coastal areas have physical problems related to the corrosive land and climate condition, as well as the possibilities of natural hazards such as flooding (ADB, 2003 : UNHABITAT 2003). The rapid growths of cities especially in developing countries (DCs) contribute to social problems, serious burdens for human health and the environment. In order to improve the quality of human life in the coastal cities, some local government decided to remove some settlements to the inland area such as problems in some big coastal cities in Indonesia. In many cases, many resettlements of housing failed to meet community's and user's requirements. To reduce and avoid sustainability problems, it is necessary to have more insight and understanding of the used of space in coastal low income housing. This paper describes the use of communal spaces for daily activities which are indicating the lack of space available in coastal settlements in order to accomodate user's needs.
\end{abstract}

Keywords: coastal settlements, low income housing, home based enterprises (HBE) activities, space used

\begin{abstract}
ABSTRAK
Banyak rumah tangga masyarakat berpendapatan rendah didukung oleh Bisnis Berbasis Rumah Tangga untuk menghasilkan pendapatan mereka. Bagaimanapun juga, permukiman di kawasan pesisir memiliki masalah fisik yang berhubungan dengan lahan yang korosif dan kondisi iklim sebagaimana kemungkinan bahaya alam seperti banjir (ADB, 2003: UN HABITAT 2003). Pertumbuhan kota yang cepat terutama pada negara berkembang memberikan kontribusi bagi masalah sosial, beban yang serius bagi kesehatan dan lingkungan. Untuk meningkatkan kualitas kehidupan manusia di kota pesisir, beberapa pemerintah setempat memutuskan untuk menghilangkan beberapa permukiman di kawasan seperti beberapa masalah yang terjadi di kota pesisir di Indonesia. Dalam beberapa kasus, banyak permukiman gagal untuk memenuhi keinginan pengguna dan komunitas. Untuk mengurangi
\end{abstract}


dan menghindari masalah keberlanjutan, penting untuk melihat dan memahami penggunaan ruang di perumahan pesisir berpendapatan rendah. Penelitian ini menggambarkan penggunaan ruang bersama untuk aktifitas sehari-hari yang memiliki indikasi kekurangan ruang yang dapat dimanfaatkan pada permukiman pesisir untuk mengakomodasi kebutuhan pengguna.

Kata kunci: perumahan pesisir, perumahan masyarakat berpendapatan rendah, kegiatan bisnis berbasis rumah tangga, ruang yang digunakan

\section{INTRODUCTION}

Currently there is an increasing pressure in many regions in the world to provide a sustainable environment for present and future generations. It involves the simultaneous pursuit of social equity, environmental quality and economic prosperity: people, planet and profit (UN 2005). Together with solving the housing problem for the urban low income households in a sustainable lifespan based manner, sustainability has become one of the most urgent imperatives in many tropical developing countries. This counts particularly for coastal settlements that have to face natural hazardous impacts (UNHABITAT 2003).

As commonly faced by the coastal areas near the sea, there is a relatively high potential for flooding or tidal flooding and sea water intrusion due to a high intensity of ground water exploitation in a densely populated areas. Even, in some coastal areas it can cause land subsidence and sea water intrusion (sea water inside to the ground water aquifer system) to the far-reaching land (Kusumaatmadja, S. 1994; Sarkowi, 2007). This decline in ground water surface could result in other disasters such as: flooding, salt water intrusion and corrosion of the environment and buil-dings construction (Zainuddin, 2004).

Low income houses $(\mathrm{LIH})$, with different layouts and space design, have been built for the lower income households through various housing programs to alleviate the housing problem in many tropical developing countries, particularly in urban densely populated areas where land is rather scarce. Not all of them have shown to be adequate or widely accepted alike in the situation of the coastal areas of Java in Indonesia (ADB 2003). Moreover newer modern construction designs and methods are obviously in place within Humid Tropical Coastal Cities (HTCCs). A large percentage of building construction still utilize the space design that appear to be unsustainable.

In order to improve the quality of human life in the coastal cities harmed with coastal environmental problems and rapid growth of the cities, some local government decided to remove some settlements to the inland area for example Jakarta and Semarang in Indonesia. To reduce and avoid sustainability problems, it is necessary to have more insight and understanding of the sustainability of space design for housing in different societies and locations in coastal areas. Given the lack of specific data and the particular context of coastal tropical urban settlements of low income households in DCs, important aspects that need to be investigated are 
functionality of space design and user requirements for the housing units in the short term and sustainable perspective.

In a developing country, such as Indonesia, housing for low income household is provided by government and developers. The space provided is based on standards from the Indonesian National Standard and of WHO, which use an area of 9 $\mathrm{m}^{2}$ /person. This area should in fact be based on domestic activities which take place in households. However, the standards did not take into account this or additional activities such as those of Home-Based Enterprises (HBE). According to Septanti (2004), 25-30\% housing in informal settlements had business activities inside the house. The standard area may bias and no longer appropriate for (future) occupants needs. Therefore, a study that aims to get new guidelines for the design space according to the activities of its inhabitants in coastal low income housing is strongly needed.

This paper will particularly explain and reflect the use of communal spaces in coastal settlements related to user's activities. The use of communal place indicates the lack of space available in user's house. However it is common in informal housing, but even if community has to move to other place (formal housing) the used of communal spsces will cause problems.

\section{THEORY / RESEARCH METHODS}

New housing designs are needed to be used in coastal areas. But it does not take place. The reason why could be found by using Innovative System Theory. The Innovation System Theory stated that a design, technology or product will be successful if it fits the prevailing technological regimes of the stakeholders' idea and expectation. If not a regime shift should be accomplished, i.e fundamental, profound, change of perception, rules (Nelson and Winter 1982, Douthwaite, 2002). Thus technological regimes guide the design and further the development of new designs, technologies, innovations and products (Dosi 1982; Nelson \& Winter 1982, van Egmond and Mohammadi, 2011).

Housing which are provided by governments often does not match with user's requirements. For the analysis of this problem, the Social Conflict Theory will used in order to meet the agreement between space designs provided by government with user's requirements. The Sociological Conflict Theory proposes a basic inequality exists between various groups thus conflicts occur. These inequalities are due to differences in socio-structural and socio-cultural backgrounds (positions, ideas, expectations) Conflicts are not intrinsically bad; they provide ground for desirable changes. Consensus between all stakeholders is needed in order to avoid conflicts (Marx \& Weber, 1883). The regime of the stakeholders may serve as a primary basis for an appropriate design to represent the characteristics and activities of inhabitants.

The evaluation design attributes is misleading without considering occupants. The occupants' space requirements of daily activities are the basic consideration for housing supplier to provide the houses space design. This research investigates the users' domestic activities based on their characteristics as the inhabitants of coastal low income housing. Due to investigate the space design, the Activity Theory can be 
used. Activity Theory as the theoretical framework has been applied in various fields such as urban planning (Fjeld, 2002). Related to Theory Activity, Engestrom (1999), proposed the scheme which three interacting entities: the individual, the object or technology and the social systems. The former scheme - the individual and the object was proposed by Loent'ev (1978). According to this theory, human activity can be broken down to some activities that become a stand-alone. All activities are influenced by the characteristics of the users and the society in which they live. The particularities of different societies can be seen in certain activities and how these activities are supported by the technology attributes (e.g. size and form of the space) that make up the space in which they occur. Thus the users' background particularities determine their activities and their requirements for space.

The on-going research investigates the problems of the sustainability of space design terms of reference for coastal low income housing in developing country such as Indonesia with a particular emphasis on the user requirements for functionality and adaptability especially to support business activities of the home based enterprises (HBE) in the communities. The space design of the housing provided to the coastal low income households in developing country such as Indonesia will be evaluated in this perspective. Post occupancy evaluation (POE) is a general term for a broad range of activities and processes of systematically evaluating the performance of buildings after they have been built and occupied for some time (Preiser, 2002; Preiser et al., 1988). In order to gain functionality of the space design, the on going research will be used POE method to evaluate the existing housing space design. The functionality determine by users' demand in order to accommodate their activities (Tipple, 2000; Manalang, 2002). The parameters that will be used are space area (size/dimension) and form. The on-going research explores the potential of space design to contribute in meeting the stakeholders' requirements for sustainability of low income houses in humid tropical coastal cities (HTCC) in Surabaya, Indonesia. The sustainability of low income houses referred in this project to the extent at which the space design attributes meet the stakeholders' requirements in terms of functionality and adaptability by using activity based approach (Figure 1).

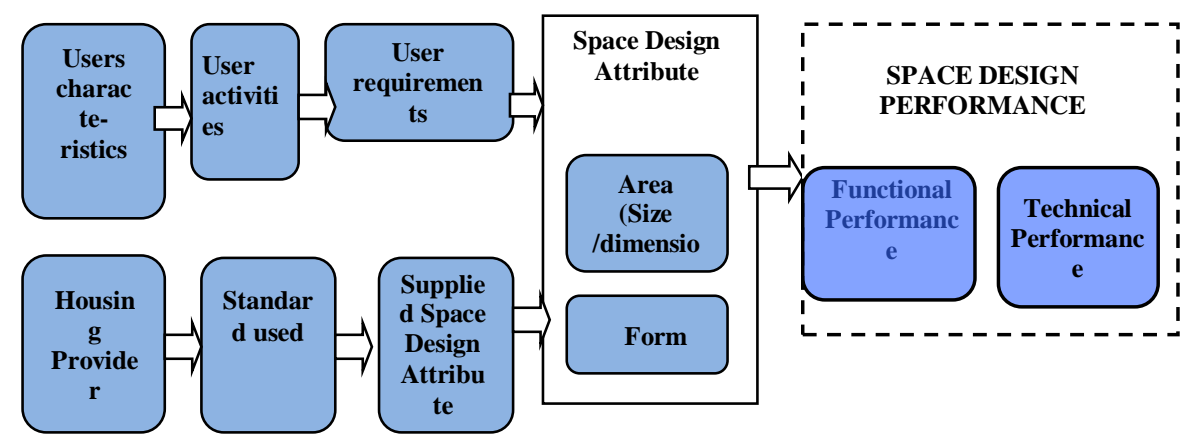

Figure 1.The Analytical Framework for Functionality and Adaptability of Space Design 
According to Ang and Groosman et. al. in Szigeti and Davis (2005), the hamburger model is a conceptual solution to investigate the gaps between client requirements for space and the space provided by the supplier. The client requirements are to be translated into a technical language represented by the design solution concept. The development of a solution concept is a design decision. The assumed or actual realization of the design concept allows for expecting the real performance of the space. This performance differs in general and shall be at least equal to the clients' requirements of space design performance.

Due to evaluate the performance and to compare alternative solutions the validation method such as space measurement can be used. A gap analysis based on calibrated scales that measure both the levels of requirements and the capability of the asset can take place by comparing the affectivity between demand and supply. The on-going research will use the hamburger model in order to investigate the potential gap between client (users) requirements and suppliers "provision of space design.

\section{Productive Housing in Coastal LIH}

Nowadays, in many developing countries (e.g. India, Indonesia, Ghana, Bolivia) many houses which usually are used as a residence are also used as place for business. It is common, especially for low-middle class households (Silas, 2000). In addition to improve the family's economy, these activities can also improve the economies of the country. Kellett (2000) argues that the HBE activities provided local service and contribution to the wider economy. Following him, many of households used their home for domestic and working place essential for survival. The labour in the formal sector needs high skills, qualifications, education and experience. These are the requirements that cannot be fulfilled by them in order to gain good job opportunities.

People who live in coastal area especially in informal settlements mostly have a close relation with the sea. Their living is supported by the sea, such as the fishermen or business activities which are based on sea products (Dahuri, 2001). Furthermore HBE activities are a way for inhabitants to sustain their livelihood. ".... The success can contribute significantly to sustainable economic development" (Tipple, et. al. 2001). Houses that have HBE usually need more spaces, but do not need better quality than houses without HBE. People uprooted for environmental reasons will look for alternative livelihoods elsewhere while at the same time remaining oriented towards both their areas of origin and their traditional way of living (off the land).

\section{Domestic and Home Based Enterprises (HBE) Activities}

This paper discusses two different categories activities which are conducted in the house: domestic activities and business (HBE) activities. Bender's in Yanagisako (1979) proposed the definition of "domestic activities" as concerned with the day-today necessities of living, including the provision and preparation of food and the care of children. Besides, Fortes (1978) pointed out that a house holding and 
housekeeping unit is organized to provide the material and cultural resources needed to maintain and bring up its members and his definition of the domestic domain as the system of social relations through which the reproductive nucleus (the family) is integrated with the environment and with the structure of the total society. The core of most conceptions of "domestic" are two sets of functional activities including those pertaining to food production and consumption and those pertaining to social reproduction, including child bearing and child rearing.

This paper which is focusing on basic business activities that conduct by inhabitant in low income housing more closed with the classification that proposed by Kellett and Tipple (2000). The activities conducted in the house are based on the HBE categories used. However every category has different kind of activities, the characteristics of activity in this paper can sharpen to 4 activities as follows: storing raw material and equipment, accepting customer, doing business activities (processsing, keeping the stores, servicing), and storing product.

\section{Research Sample}

The study area is the Surabaya Coastal Area (CSA) which consists on 13 districts and 25 subdistrics. For the study with a large population, the determination of the sample can be done by cluster random sampling taken at the district contained on the site. This research randomly took 6 districts and 8 sub districts that are used as site studies. They are Tambak Osowilangun, Morokrembangan, Sukolilo, Tambakwedi, Keputih, Kejawan Putih Tambak, Medokan Ayu and Gunung Anyar Tambak.

The population in the study area was about 36,100 people in 2011 (Source: Surabaya City Planning Board, 2011). The population in SCA is rather heterogeneous, ranging from very high income classes in the formal settlements to the relative poorer inhabitants income categories in informal settlements. In order to meet the research objective, the research population is the low income housings which are built by community. The low income housings built by the community were about 8025 units. 25 - $30 \%$ of them have Home based Enterprises inside the house (i.e. 2265 units) with 97 respondents were taken.

\section{RESULTS AND DISCUSSION}

\section{The Classification of Housing in Coastal Settlements}

Some authors using many kind of classification to classify low cost housing typology. Santosa (2000) classified the housing by the type of housing built (in the middle of street, on the corner, in the main road) and Rahmawati (2009) classified by the way built the house (house that built in the middle of plot, one side on the plot and two side plot. Both of authors will see the influence of housing position with the kind of space using. The position of house built will give effect to how people using their house. Other classification, Indonesian National Standard used the housing sizes of the house (i.e. $18 \mathrm{~m}^{2}, 21 \mathrm{~m}^{2}, 36 \mathrm{~m} 2$ ). 
This ongoing research will stress on the influence between activities, the kind of room and space area needed. The classification will follow the availability of houses to provide the specific place for business activities. In this research, the classification will be divided to two categories as the following: housings which have specific place for business activities and housings which have no specific place for business activities.

The research was conducted in 97 households with the range area between 36 to $84 \mathrm{~m}^{2}$. Each those category will be also classified into other three different housing size area categories i.e. bellow $36 \mathrm{~m}^{2}$, between $36-70 \mathrm{~m}^{2}$, and more than $70 \mathrm{~m}^{2}$.

\section{Percentage of housing type in coastal low income housing}

\section{$\square \mathrm{H} 1 \square \mathrm{H} 2 \square \mathrm{H} 3 \square \mathrm{H}_{4} \square \mathrm{H} 5 \square \mathrm{H} 6$}

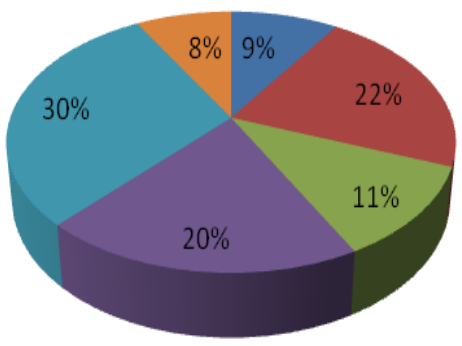

\section{The comparation of housing type in coastal low income housing}

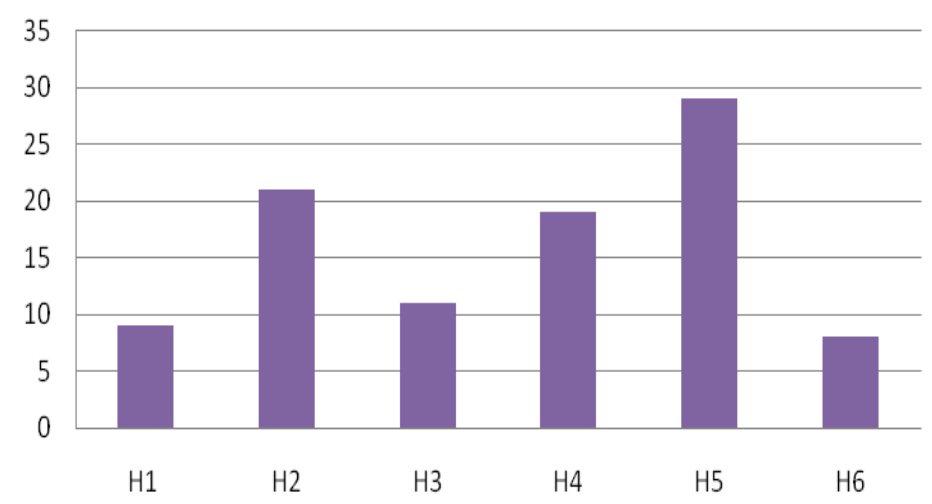

Figure 2. The Housing Classification 
Table 1. The Classification of Housing in Coastal Settlements

\begin{tabular}{lcccc}
\hline CLASSIFICATION & $\mathbf{3 6 \mathbf { 3 2 }}$ & $\mathbf{3 6} \mathbf{M 2}-\mathbf{7 0} \mathbf{\text { M2 }}$ & $\mathbf{2 7 0 \mathrm { M } 2}$ & TOTAL \\
\hline $\begin{array}{l}\text { Housings which have } \\
\text { specific places for HBEs) }\end{array}$ & Housing type 1 & Housing type 2 & Housing type 3 & $42.26(\%)$ \\
& 9 & 21 & 11 & \\
Housings which have no & Housing type 4 & Housing type 5 & Housing type 6 & $57.73(\%)$ \\
specific places for HBEs) & 19 & 29 & 8 & \\
Total & 28 & 50 & 19 & 97 \\
Percentage $(\%)$ & 28.89 & 51.54 & 19.58 & $100 \%$ \\
\hline
\end{tabular}

\section{The Activities of Local Community in Communal Space}

Based on the results, activities in coastal low income housing (both domestic and $\mathrm{HBE}$ ) are very large. People used almost all of their sources and surrounding sources include space. Not only their existing space, but also some community places are used to support or their activities. Several respondents used the communal facilities (toilet, paving path (local road path). However people had their own specific places but the used of communal facilities were also needed. This will cause difficulties if they move to formal houses. Formal houses have specific room/space for every family (houses). In the formal housing are not common to used communal space for domestic or HBE activities. Almost $42.26 \%$ respondents have specific places for $\mathrm{HBE}$, but the spaces do not only inside of the house/plot (private space) but also in communal place.

Table 2. The Average Size Used in Communal Space

\begin{tabular}{lcccccc}
\hline \multicolumn{1}{c}{ ACTIVITY } & \multicolumn{6}{c}{ THE AVERAGE SIZE USED (M2) OF COMMUNAL SPACE IN } \\
CLASSIFICATION & $\begin{array}{c}\text { Housing } \\
\text { type 1 }\end{array}$ & $\begin{array}{c}\text { Housing } \\
\text { type 2 }\end{array}$ & $\begin{array}{c}\text { Housing } \\
\text { type 3 }\end{array}$ & $\begin{array}{c}\text { Housing } \\
\text { type 4 }\end{array}$ & $\begin{array}{c}\text { Housing } \\
\text { type 5 }\end{array}$ & $\begin{array}{c}\text { Housing } \\
\text { type 6 }\end{array}$ \\
\hline HBE & 3.40 & 3.76 & 0.27 & 3.56 & 4.3 & 1.2 \\
Domestic & 0.82 & 0.53 & 0.22 & 1.72 & 0.76 & 0 \\
Total & 4.42 & 3.29 & 0.49 & 5.28 & 4.06 & 1.2 \\
\hline
\end{tabular}
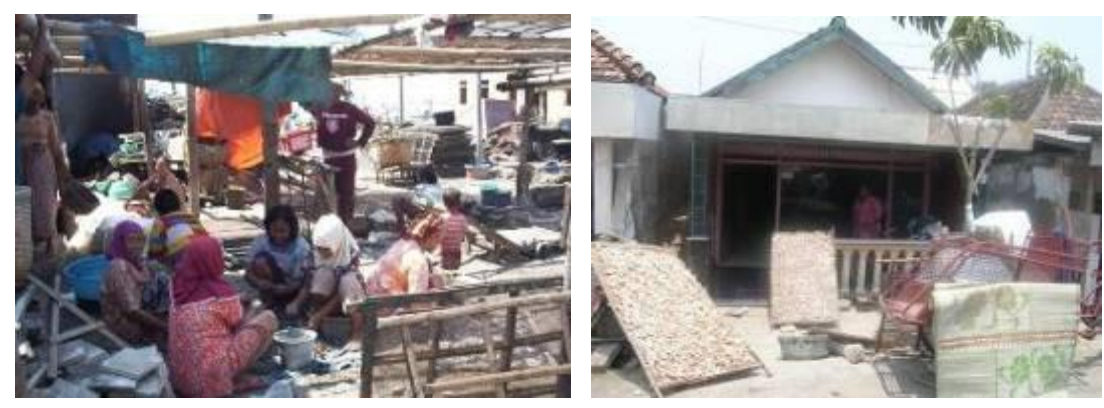

Figure 3. The Used of Communal Spaces for Working Place to Gain Income Generations 
Table 2 shows houses with same size need more space in communal place to conduct their activities (both domestic and business). The needs of space in housing type $4(<36 \mathrm{~m} 2)$ were higher than house type 1 because they have no specific place for HBE activities. The same also with housing type 2 and 5 as well as housing type 3 and type 6.

\section{The Adaptable Space by Local Communities}

However people had limited space for activities, the innovative adaptable spaces were needed to cover user's requirements. Some adaptable spaces applied in coastal low income housing are as the following:

1. The used of space for multifunction activities

The used of room as multifunction space is common especially for low-income people that have no many resources to improve the quality of their houses. From the diagrams bellow it can be seen that one room can be used as different kind of activities. HBE activities will be conducted after most of the other family members out of the house for work or school. So that, HBE operator (i.e. people who work for $\mathrm{HBE}$ ) can use the space/room freely.

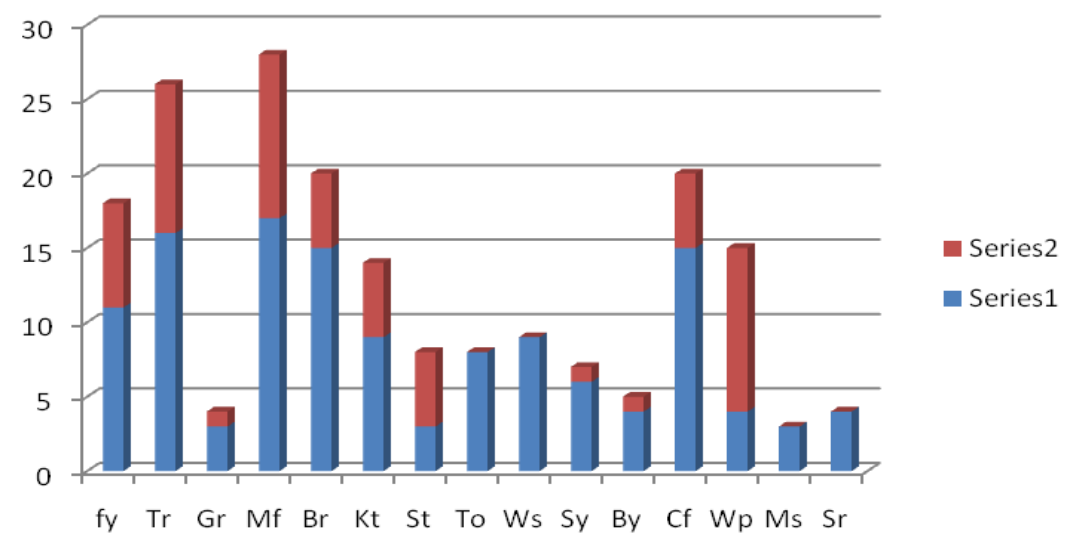

Figure 4. The Comparison of Room Used for Domestic and HBE Activities

The domestic and business activities were overlapping in: front yard, terrace, multifunction room, bedroom, kitchen, storage, side yard, backyard, communal facilities, working place. The most functional rooms used for domestic and HBE activities were: family room was always used for both domestic and $\mathrm{HBE}$ activity in different kind of function such as: as a bedroom, as guest room, for family gathering, relaxing activity (multifunction space), terrace was used for domestic activities and some of houses used this room for HBE activities, and bedroom was used for sleeping, praying, learning/reading.

2. Using specific space for $\mathrm{HBE}$

Some households provide a special place for HBE so they do not interfere with the activities of other family members. Almost $42.26 \%$ of respondents have 
specific place for HBE. This kind of solution is more effective in terms of the use of space or time usage. Moreover, HBE activities can carry out without dependence on domestic one. The activities can be done any time in accordance with the time they needed.

3. Time arrangement

The arrangement of time prioritizing activities or person which is the most important is a way to customize the space in order to solve the conflict of needs for different types of activities. For example: between domestic and $\mathrm{HBE}$ activities as well as between domestic activities which are have different characteristics i.e. learning/reading (requires a quite atmosphere) with children's playing. The arrangements of time sharing were not enforced significantly, but every family member can be managing according to their requirements. This figure (Figure 5) shows how the time arrangement applied according to carried out users needs of space.

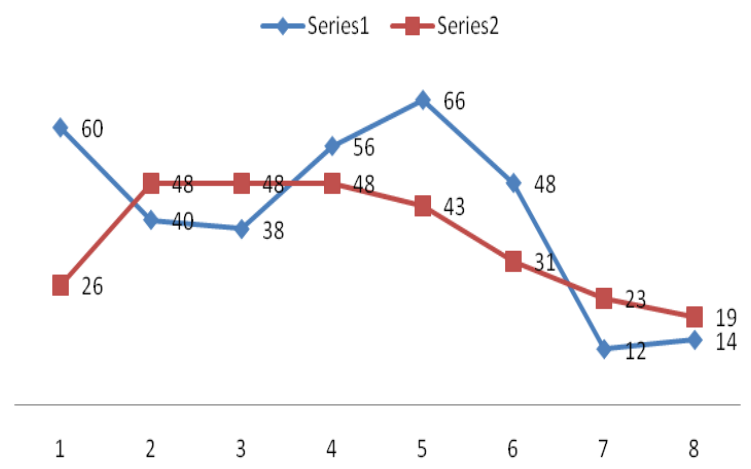

Figure 5. Activities vs. Time

4. The arrangement of activities characteristics

If an activity is considered more important than other activities, the activity will take precedence (precedence over other activities). For example HBE activities deemed more important instead of receiving guests, the business is still going well whilst receiving guest activities can be done in other places, such as on the terrace. Vice versa, if the domestic activities are more important, these activities will be prioritized, while business activity can be stopped for a moment or moved to other places.

\section{CONCLUSIONS}

The expansion spaces of low income housing are conducted in order to meet the shortage of space that is not available in the house. Communal space is commonly used in informal low-income housing. In informal housing, the lack of available space for both domestic and HBE activities causes strongly the need for using this communal space. Houses with business inside need a special room for $\mathrm{HBE}$ 
activities. The research result showed that houses with same size but without special place for HBE use bigger communal space than houses with special place for HBE.

\section{REFERENCES}

Choudhary, N (2009), Women's Economic Contribution through Their Unpaid Household Work: The Case of India, Nagpur, India.

Dahuri, R. et al (2001), The Comprehensive Management for the Source of Coastal Area, Pradnya Paramita, Jakarta.

Davidson, N. et al (2006), The Multispace adaptable building concept and its extension into mass customization, Paper/Proceedings in International Conference On Adaptable Building Structures, TU/e Eindhoven, the Netherlands.

Engeström, Y. (1999) Innovative learning in work teams: analyzing cycles of knowledge creation in practice, in: Y. ENGESTRÖM et al (Eds.) Perspectives on Activity Theory, (Cambridge, Cambridge University Press), 377-406.

Fjeld, M. et al. (2002), Physical and Virtual Tools: Activity Theory Applied to the Design of Groupware, Journal of Computer Supported Cooperative Work 11(1), 153-180, Kluwer Academic Publishers, The Netherlands.

Indonesian National Standard (2011), UU No. 1/2011 Housing and Human Settlements.

Kusumaatmadja, S. (1994), Handling Urbanization Being National Policy, Kompas, Jakarta.

Leont'ev, A.N. (1978), Activity, Consciousness, and Personality, Prentice- Hall, Moscow, Russia.

Mahmud, S. (2003), Women and the transformation of domestic spaces for income generation in Dhaka, Journal of Cities, 20 (20),1-10, Elsevier Limited, UK.

Mahmud, S. (2003), Women's Vocational Training and Using of Domestic Spaces for Income Generation in a Low-Income Settlement: A Case of Resettlement Camp in Dhaka, Bangladesh, Unpublished Dissertation, King Faisal University, Saudi Arabian.

Marfa'i, M. A. et al (2008); The Impact of Tidal Flooding on a Coastal Community in Semarang, Environmentalist Journal, 28 (1), 237-248, Springer Science + Business Media, LLC.

Marwasta, D. and Kuswadji, D. (2005), The Analysis of Rural Settlement Characteristics on The Coastal Area in District of Kulonporogo; Research Report, Gajah Mada University, Yogyakarta, Indonesia.

Ministry of Public Work (200x), Indonesian National Standard for Low Income Housing, Ministry of Public Work, Jakarta.

Preiser, W. (2002), Intelligent office building performance evaluation, Journal of $\mathrm{Fa}$ cilities, 20 (7/8), 279-287, Emerald Books, UK.

Sarkowi, A. (2007), The Rate of Subsidence in coastal area (Case Study Semarang, Indonesia), Unpublished Dissertation, Bandung Institute of Technology, Bandung, Indonesia. 
Septanti, D and Setyo Wibowo, A. (2004), Study for Quality Improvement of Urban Slums Area, Research Report, ITS Research Centre, Surabaya, Indonesia.

Septanti, D. (2000), Room Utilisation Pattern for Home Based Enterprises (DIK Research Report), ITS Research Centre, Surabaya.

Silas, J. (1989), Marginal Settlements in Surabaya, Indonesia; Potential or Problems, Journal of Environment and Urbanization, 1 (2), 60-70, Sage Publication, International Institute of Environment and Development, UK.

Szigeti and Davis (2005), Performance Based Building: Conceptual Framework, CIB, The Netherlands.

Tipple, G and Kellett, P. (2000), The home as workplace: a study of income generating activities within the domestic setting, Journal of Environment \& Urbanization, 12 (1), 203-214, Sage Publication, International Institute of Environment and Development, UK.

Tipple, G and Kellett, P. (2003), Exploring Space: Researching the use of domestic space for income generation in developing cities, Paper/Proceedings for ENHR, IAPS and KTH International Conference: Methodologies in Housing Research, September 2003, Stockholm, UK.

Tipple, G. (1996), Housing Extensions as Sustainable Development, Journal of Habitat International, 20 (3), 367-376.

Tipple, G. et.al. (2002), The effects of home-based enterprises on the residential environment in DCs in Building Sustainable Urban Settlements : Approach and Case Studies in the Developing World, S. Romaya and C. Rakodi (Eds) ITDG Publishing, London-UK.

United Nations (2003), Coastal GTOS Geostrategic Design, <http://www.fao.org /docrep/008/a0266e/a0266e07.htm>, (Accessed on June 12 2012).

UN-HABITAT and GUO (2003), Guide to Monitoring Target 11: Improving the Lives of 100 Million Slum Dwellers, 2003, <http://www.unhabitat.org/pro grammes/guo/documents/mdgtarget11.Pdf>, (Accessed on June 12 2012).

Van Egmond, E and Mohammadi, M. (2011), Innovations in domotics : Fulfilling Potential or Hampered by Prevailing Technological Regime, Construction Innovation: Information, Process, Management, 8 (4), 470-492, Emerald Gro up Publishing Limited, UK.

Van Egmond, E. (2000), Technology Mapping for Technology Management, Dissertation, Technical University of Delft, the Netherlands.

Yanagisako, S. J. (1979), Family and Households: The Analysis of Domestic Groups, Annual Rev. Antrophology, 8(1), 161- 205, Annual Reviews Inc., Stanford University, Stanford Salifornia, USA.

Zapata, D. (2006), Counting invisible workers: Girls in domestic activities within their Homes, UNICEF, Innocenti Research Centre, Florence, Italy. 